\title{
The Festival of Kromong Mountain as a Glorification of the Value of the Natural, Social, Economic, and Cultural Arts in Cirebon, West Java, Indonesia
}

\author{
Jaeni \\ Theater Department, \\ Performing Arts Faculty \\ Indonesian Cultural Arts Institute Bandung \\ Bandung, Indonesia
}

\begin{abstract}
The Mountain Kromong Festival was conceived by researchers as an annual activity aimed at communicating art in realizing cultural engineering in a society that was contaminated with industrial culture. This festival is held right in the Gempol District of Cirebon, West Java, Indonesia to reassemble the cultural traditions of the mountain/huma community, which so far have covered the lives of industrial communities. Maintaining this form of festival is tantamount to maintaining value, so the value of the Mountain Kromong festival is always directed at the value of environmental glorification, both natural, social, economic, and cultural arts.
\end{abstract}

The method used by researchers through participatory research stages, focus group discussions, revitalizing cultural arts, packaging festivals, and festival performances. The results of a series of research work on the Cirebon mountain kromong festival became a model of a mountain festival different from other mountain-themed festivals. The cultural closeness of all Mount Kromong festival materials is sourced from the local community, both artistic and aesthetic related matters.

The entire series of festivals that have been running for two years, resulting in a cultural movement that is contained in Mountain Kromon performing art. Mountain Festival kromong increasingly in development right in the economic empowerment through the development of arts and culture-based tourism.

Keywords:- Mountain Kromong Festival, Communication Performing Arts, Arts and Culture, Tourism, Environment.

\section{INTRODUCTION}

The establishment of the Tiga Roda cement factory in the village of West Palimanan, Gempol sub-district, Cirebon district for approximately 30 years, began to show the socio-cultural impact on the surrounding community. The socio-cultural impact was not only felt by the people of the village of West Palimanan who became the center of PT. Semen Tiga Roda, but also felt by other village communities, such as the villages of Gempol,
Cikeusal, Kedung Bunder, Cupang, and Walahar which are around the factory.

Social and cultural impact on the community is part of the dynamic process of transition society and also reveals the effects of the other, such as the ecological balance, economic, and social welfare. This has greatly influenced the socio-cultural life of the people in villages in Gempol sub-district, especially in West Palimanan village, Gempol village, and Kedung Bunder village which are located right in the middle of the activities of the three-wheeled cement factory industry.

The socio-cultural life of the West Palimanan village community affected by the impact of industrialization is further from the character of the village people who live full of mutual cooperation, maintaining cultural traditions, including preserving the natural environment. There is no longer any paddy community activity, let alone traditional ceremonies that could guarding the cosmos of their lives.

The emergence of the industrial era should not eliminate the values of life or national pillars concerning the maintenance of ecology / nature for the sake of environmental balance, socio-cultural life that can create harmony, increase the economy for the welfare of its people. Many things must be done to realize the pillars of nationhood Thus, according to the capacity of researchers in the field of arts and culture, social engineering is needed in the form of cultural arts festivals as a social action which is at the same time an effort to revive their Cultural and artistic traditions that store the values and local character of the people.

Socio-cultural change in society is a logical consequence of social change, which by Himes and Moore (Soelaiman, 1998: 115) are identified as having structural, cultural, and interactional dimensions. These dimensions can be noted as an effort to find solutions to minimize the effects of social change community culture. While Ogburn (1932) in Social Change noted that social change will also involve changes to the technology used in people's lives that will result in changes to the material environment and how to regulate it, and cause changes to the habits in social institutions. On the cultural side, social change according to Sorokin (1956) is a journey of cultural mentality, from an ideational, sensory, to idealistic mentality by looking at 
changes in Western society in the twentieth century. Indonesian society when faced with social change, means the journey of mentality only reaches the material mentality that is material This Inderawi mentality must be combined with the previous mentality, namely the non-material ideational mentality. This is to get a handle in facing sociocultural changes with an idealistic mentality, namely the merging of the ideational with the senses.

Even though Sorokin exemplifies Western society, it does not mean that Indonesia has to become Western. What Sorokin said can be an inspiration for people in villages in Indonesia to respond to socio-cultural changes with awareness of the existence of a community mentality journey. In other words, this awareness in the perspective of social and cultural change will enhance human progress and avoid the negative effects of social change (Salim, 2002: 182).

Through the theoretical notes that have been explained above, it seems that social changes in society that tend to have a negative impact on people's lives can be guarded by the cultural activities of the people who used to be basic values in their lives. The emergence of technology needs to be accompanied by cultural piety that society has. The reasons that encourage the idea that forms of cultural activity deserve to be blamed as social action that can guarantee the emergence of social cultural change in the midst of society. This idea can trace Jean-louis Fabiani's opinion (2011: 95) when researching the Avignon Theater Festival in France. For Fabiani, cultural estates such as the Avignon Theater Festival belong to the people of their environment which can serve as a reminder of collective memory as social capital to avoid atomization. (social divisions). Referring to the opinion, the form of cultural arts festival held by the community, would be a solution in building the pillars of nationalism in the atmosphere of social and cultural changes in society today. In that regard, the activities Festival Mount Kromong, in District Gempol, Cirebon, be one solution to a problem that must be realized by the activists of art and culture and related agencies, including the Department of Tourism and Culture Pro p insi West Java, Indonesia .

Festival Mount Kromong as a form of environmental breeding aims to $\mathrm{p}$ elestarian folk art and culture that in their neighborhood. Considering the background of the industry which has curved, the purpose of this study is also to strengthen the ties of brotherhood between communities. Some other objectives include; $m$ enciptakan pooling assets and the nature of art and culture, m embangun creative economy through space community festivals, and the most important is penanaman back local values in order to uphold the pillars of nationhood.

\section{METHODS}

Seeing the purpose of this study, the method used in this study is to combine research with service work. The method is analogous to the strategy of achieving the goals and targets of the program in overcoming problems faced by the community as follows: 1) Conducting research with participatory action; 2) Organizing young people, friendship with officials, and embracing cultural artists in the area; 3) Revitalizing local art and culture; 4) Organizing training / workshops for organizing festivals; 5) Make a unique performance packaging (Gunung Kromong performing art ); 6) Organizing kromong performances or festival; 7) Establish cooperation with the government for the sustainability of economic development programs through festivals and tourism development .

Following is the flow of the method used in research into service, as shown below.

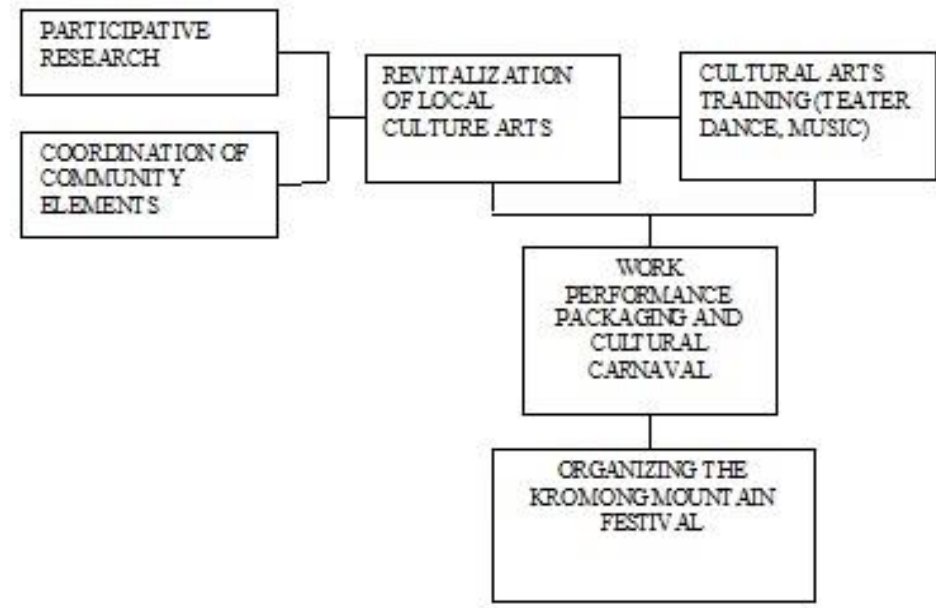

Fig 1:- The Flow of Research Methods (Source; Researcher)

\section{RESULTS AND DISCUSSION}

\section{A. A Glance About Kromong Mountains}

Kromong Mountains is a line of hills that forms small mountains along the border areas of Cirebon and Majalengka. Mountains Kromong is also interpreted as a mountain cluster as a barrier between the people of Cirebon Regency and Majalengka. Small mountain range that is exposed from Gempol, palimanan, until Bobos believed by some communities in her, that Mount Kromong is a "Chunks of Gold" a heritage that was given as a preparation for the people around him.

"Gold Chunk" in the Mount Kromong area is a hidden potential that cannot be interpreted denotatively. Under the Kromong Mountains cluster are community groups that used to be very dependent on the resources of the mountain cluster. Like communities in Palimanan Cirebon, Kromong Mountains became their source of life, both in terms of economic, social and cultural aspects. In the area there are hot springs (banyu panas) which ejects a natural hot water with levels of sulfur which is great for treatment. Kromong mountains contain minerals that can be exploited 
for the benefit of industry, such as the natural andesite stone and lime stone.

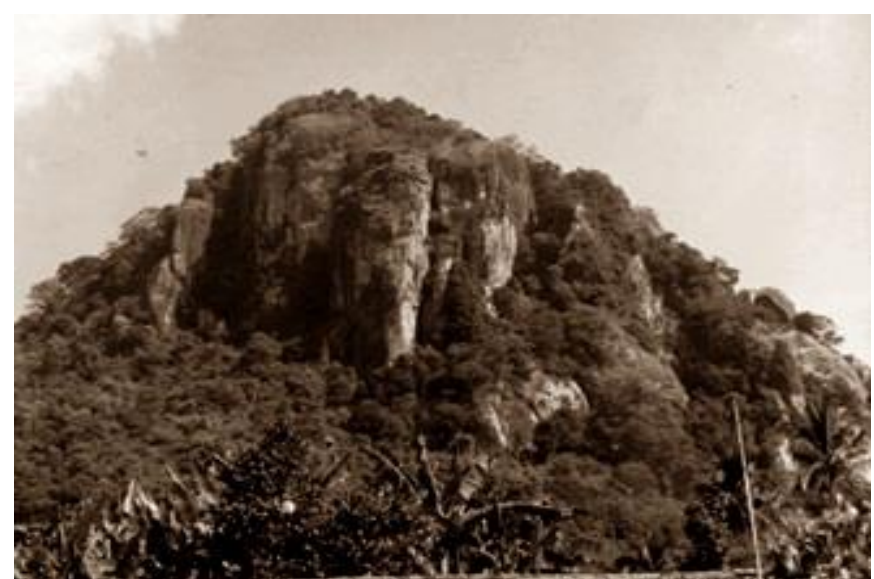

Fig 2:- Cave Dalem Palimanan Cirebon, West Java, which until now still stands as part of the Cirebon kromong mountain cluster (source; Researcher)

Some heritage sites become part of the cultural life of the community, such as the site tomb of Ki Buyut palimanan, Petilasan Sunan Bonang, Cave Lawang sanga, Cave palace, Tiger Cave, Cave Topong, and Lawa Cave. Dalem Cave, Topong Cave. Likewise with the potential of art owned by the local community, such as masks palimanan, sintren, puppet, genjring rudat, weeks ublung, plays, bajidur, and be some a other performing arts that if excavated may dipotensikan be a tourism asset arts and culture and religion of West Java.

\section{B. Packaging Work of The Festival of Kromong Mountain}

In this activity the author focuses on the packaging work of the Festival of Kromong Mountain. The festival packaging is divided into three categories of performances, namely cultural performances that contain iderideran; afternoon performance by displaying the rampak mask of Ciluwung (Palimanan); and the staging of the Kromong Mountain performing art as the peak event at the Mount Kromong festival. The form of the Festival of Kromong Mountain is displayed as follows :

$>$ Ider-ideran (procession) which will be held in the morning (07.00 until 10:00 am). The contents of the ider-ideran event are:

- Ider-ideran of Community Creativity ;
- Drum Band \& Marching Band performances ;

- Genjring, and other arts.

$>$ Palimanan Mask Grouping, Parade Band, and Creative Industry Exhibition for the public in the afternoon until the afternoon (10:00 am to 05:00 pm)

- Palimanan Klana mask mask that is followed by children and young women;

- Parade Band Public Band filled by the Group that are around are a mountain Kromong and Cirebon district .

$>$ Kromong Mountain Performing Art is the highlight of the event at night $(07.30 \mathrm{pm}$ to $10.00 \mathrm{pm})$. "Mount Kromong Performing Art" is filled with various forms of regional art which is a traditional art community around the Gempol District area which consists of arts such as; Theatrical, Mask Ciluwung, Genjring, Sintren, and rock-percussion.

Culture parade in Cirebonese ider-ideran was conceived since the first Kromong Mountain festival. Ider-ideran in the concept of theater of the road carried out by the community around Kromong Mountains. All the artistic displayed is made by the community and coordinated by a committee of the Festival of Kromong Mountain.

Meanwhile, during the daytime performance, the Kromong Mountain committee provided space for all the potential artistic creativity of the people around Kromong Mountains by presenting a band festival and Palimanan mask grouping. The Band Festival is limited to only 15 participants, while mask grouping is attended by children and young women who learn palimanan masks, as a form of appreciation for the palimanan mask maestro, Ms. Suji, who is hardly recognized by the local government.

The Mountain Kromong performing art is the peak event which was worked on by the writer through the process of training, dirty rehearsals, and clean rehearsals. The Mountain Kromong performing art $i$ packaged in the form of collaborative music, dance and theater. The packaging of this show proves the way of packaging theatrical or large performances using pointers in the form of show fiction. Bedrip mountain kromong performing art is shown as follows:

Scenography Mountain Kromong Performing Arts 
- THE MAN'S of THE DALEM CAVE

80 minutes duration

\begin{tabular}{|c|c|c|c|c|}
\hline Scene & conjection & materials & $\begin{array}{c}\text { information } \\
\end{array}$ & duration \\
\hline 1 & Opening music & $\begin{array}{c}\text { Genjring } \\
\text { Klana mask } \\
\text { Sintren } \\
\text { Rock / percussion } \\
\text { Gamelan skits } \\
\end{array}$ & $\begin{array}{l}\text { The atmosphere of the ritual continued } \\
\text { with a cheerful atmosphere welcoming } \\
\text { the scene }\end{array}$ & 15 minutes \\
\hline 2 & $\begin{array}{c}\text { Play, dance and } \\
\text { music }\end{array}$ & $\begin{array}{l}\text { Giant role play } \\
\text { Mask personnel } \\
\text { Gamelan skits } \\
\text { Rock / percussion }\end{array}$ & $\begin{array}{l}\text { The atmosphere in the palace, cheerful } \\
\text { music and dance in bedrip one was } \\
\text { shocked by the presence of a giant that } \\
\text { emerged from behind the cave. } \\
\text { The giant observed the people who were } \\
\text { dancing rumyang masks and surprised } \\
\text { them, the masked group dispersed, } \\
\text { the giant advised the Palimanan } \\
\text { community not to disturb the palace area }\end{array}$ & 10 minutes \\
\hline 3 & $\begin{array}{l}\text { Play and music } \\
\text { (singing) }\end{array}$ & $\begin{array}{c}\text { Community play (two } \\
\text { young men) } \\
\text { Sintren personnel } \\
\text { Gamelan skits } \\
\text { Genjring }\end{array}$ & $\begin{array}{l}\text { The atmosphere of community } \\
\text { entertainment with genjring combined } \\
\text { with theatrical gamelan, accompanied by } \\
\text { dance (sintren troupe), came two young } \\
\text { men (Kasat and Kusut) having a dialogue } \\
\text { about: the residents were so happy, but } \\
\text { now many disasters began, the } \\
\text { environment / nature had been damaged, } \\
\text { a bare mountain, epidemic diseases, } \\
\text { people's lives are getting more } \\
\text { selfish. One of the young men sang a } \\
\text { memorable song about the beautiful } \\
\text { Cirebon }\end{array}$ & 15 minutes \\
\hline 4 & $\begin{array}{l}\text { Play and music } \\
\text { (singing) }\end{array}$ & $\begin{array}{c}\text { Community play (two } \\
\text { women) } \\
\text { Giant } \\
\text { Gamelan skits } \\
\text { Rock / percussion }\end{array}$ & $\begin{array}{l}\text { The atmosphere of the village near the } \\
\text { palace inside. Two women (girl and } \\
\text { maid: Slondom), they were selling at the } \\
\text { corner of the palace inside the corner. A } \\
\text { girl sings a song about a corner shop and } \\
\text { another song ( } 2 \text { songs). A maid danced } \\
\text { and occasionally joined the story of the } \\
\text { stall (while playing). Suddenly the girl } \\
\text { was kidnapped by a giant to be a } \\
\text { sacrificial palace palace. While bringing } \\
\text { a girl to the palace cave, the giant } \\
\text { advised: that do not make immoral stalls } \\
\text { and trouble, the palace cave environment } \\
\text { is a sacred and sacred environment. }\end{array}$ & 20 minutes \\
\hline 5 & $\begin{array}{l}\text { Play and music } \\
\text { (singing) }\end{array}$ & $\begin{array}{c}\text { Community play (two } \\
\text { young men) } \\
\text { Sintren personnel } \\
\text { Gamelan skits } \\
\text { Genjring }\end{array}$ & $\begin{array}{l}\text { Two young men heard that there were } \\
\text { people who made sacrifices in the } \\
\text { palace. They came to the inside of my } \\
\text { mouth. They had a dialogue while } \\
\text { begging for human casualties. They sing } \\
\text { the cerbonan song with the theme of } \\
\text { petition (gratitude), while accompanied } \\
\text { by genjring music and the Sufi troupe of } \\
\text { the Sintren group. }\end{array}$ & 10 minutes \\
\hline 6 & Closing music & $\begin{array}{c}\text { Gamelan skits } \\
\text { Genjring } \\
\text { Rock / percussion }\end{array}$ & $\begin{array}{l}\text { Collaboration of music and songs of } \\
\text { gratitude, cheerful atmosphere, all artists } \\
\text { and crew take the ride }\end{array}$ & 10 minutes \\
\hline
\end{tabular}




\section{Ider-ideran (Cultural Parade) in the Festival of Kromong Mountain}

In the ider-ideran party (a cultural parade) involving 75 groups from 3 villages (West Palimanan, Gempol, and Kedung Bunder), 750 people performed. This cultural parade features many animal replicas, both terrestrial and aquatic animals, also the imaginary animals of the local community, as well as other objects or items that are part of the imagination of the local community. This cultural march was carried out by traveling along the BandungCirebon highway with a distance of approximately $3 \mathrm{~km}$ and taken for 2.5 hours.

The cultural march took place from 07.30 until 10:00 am until it entered the Palimanan mountain kromong festival area. This cultural march was enough to attract the attention of the community along the parade location road filled with local residents, from children to adults. This cultural parade also had a traffic jam of around 1.5 hours, but nothing happened to disrupt the social life of the people of the area, even becoming a unique sight so far. The following is a picture / photo of the ider-ideran activities in the Mount Kromong festival.
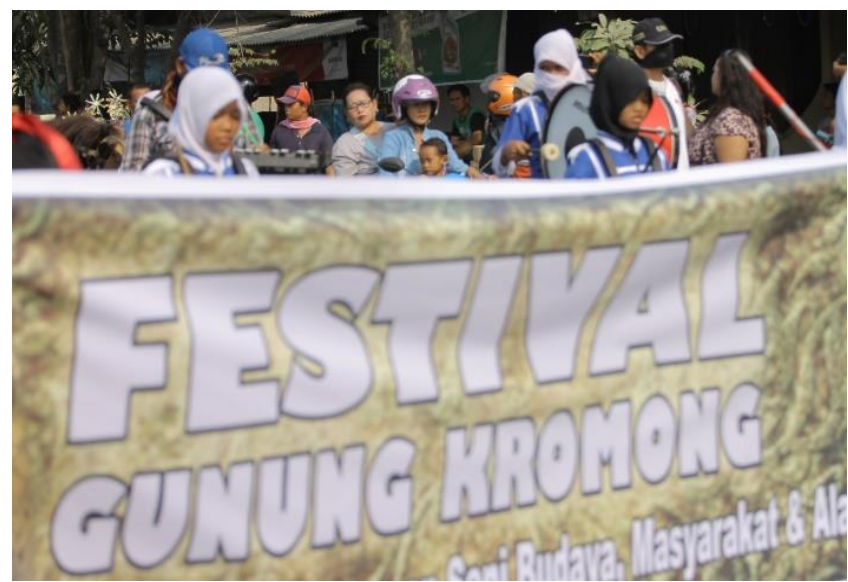

Fig 3:- Ider-ideran Mountain Kromong Festival (source; Researcher)

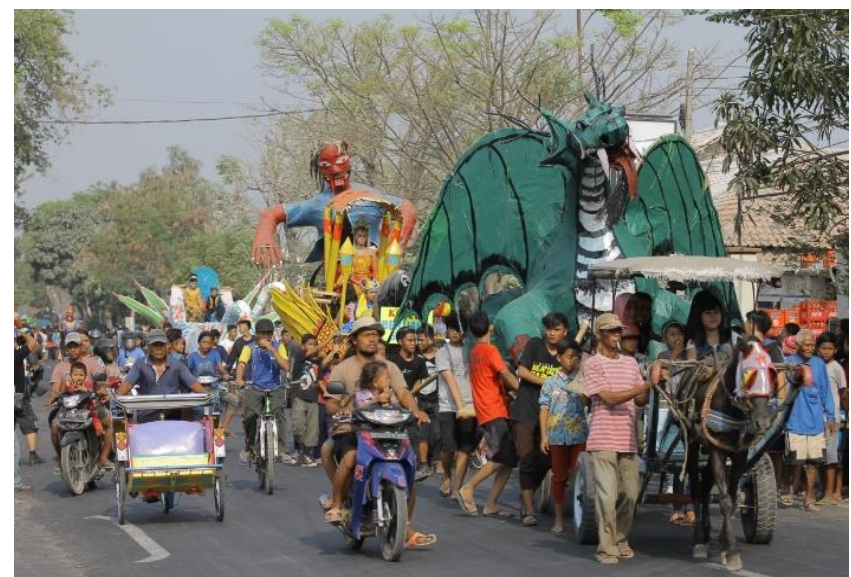

Fig 4:- Procession Ider -ideran kromong mountain festival (source; Researcher)

\section{Mountain Kromong Performing Artat the Mount Kromong Festival}

In the evening, the Mountain Kromong festival starts from 08:00 to 11:00 pm with the main show being Mountain Kromong Performing Art. The Mountain Kromong Performing Art involved 60 artists and was supported by the committee of the Mountain Kromong festival by involving residents of 3 villages of 40 people. The show begins with the opening music of the Mountain Kromong Festival which features the Kromong Genjring and is accompanied by a children's rudat dance, as part of the process of welcoming the public to come to visit the festival.

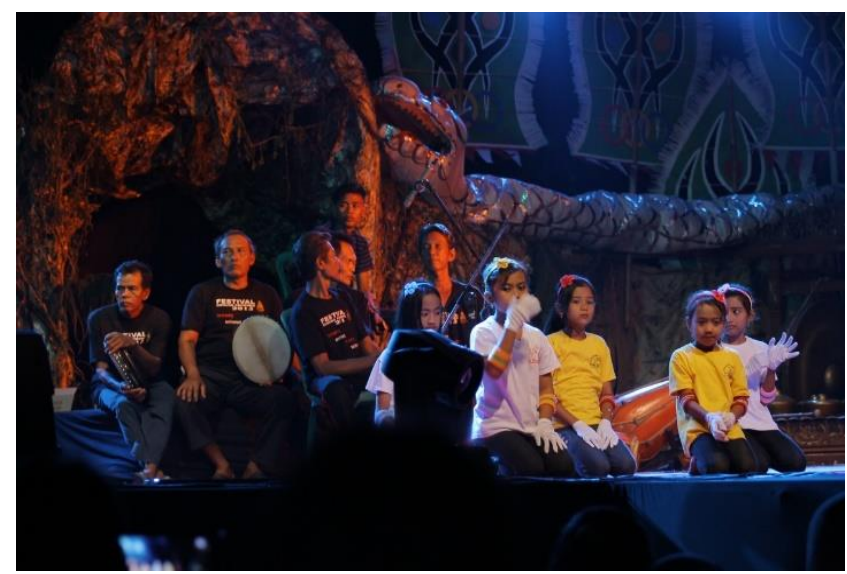

Fig 5:- Rudiment Genjring as a Welcome Presentation at the Mountain Kromong Festival (source; Researcher)

As part of the tradition of performing in the midst of the community, events like this are always accompanied by remarks, both from the committee and the local apparatus. On the occasion of the festival this time, a warm welcome was conveyed by the village head of Kedung Bunder as the person who has power over the festival venue, then continued by the head of the festival committee represented by local youth elements, and finally the remarks from the Gempol Sub-District represented by subdistrict officials. successively presented pictures / photos of local officials and the committee giving remarks at the evening event.

After the remarks, the performance at the Mountain Kromong festival continued with the performance of the Mountain Kromong performing art. The Mountain kromong performing art is the top event in the evening were filled with various forms of local arts local and collaborated with modern art. As for the arts that were presented include theatrical, Ciluwung Mask (Palimanan), Genjring, Sintren, and rock-percussion. This collaboration is packaged in the form of a musical theater which includes elements of music, theater, and dance by carrying the story "The Man's of The Cave Dalem". This play is a local community story that tells of a sacred place believed to be inhabited by spirits of the incarnation of the ancestors of the Gempol and Palimanan communities. Here are pictures / photos of the performances of the Mountain Kromong performing art in the storyline "The Man's of The Dalem Cave". 


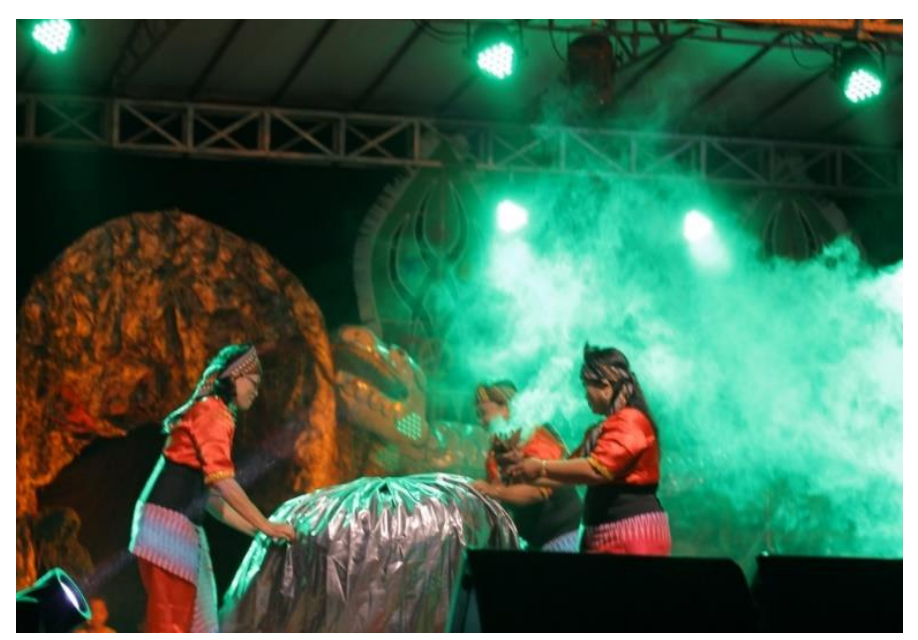

Fig 6:- Sintren as the initial scene of the palace play, Mountain Kromong Festival (source; researcher)

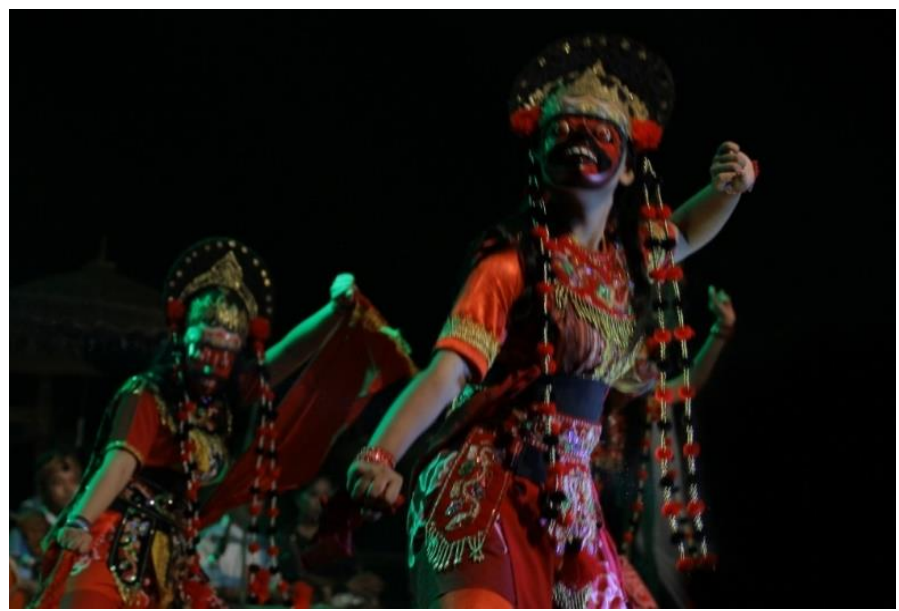

Fig 7:- Palimanan Mask as Part of the Palace Play Scene, Kromong Mountain Festival (Source; Researcher)

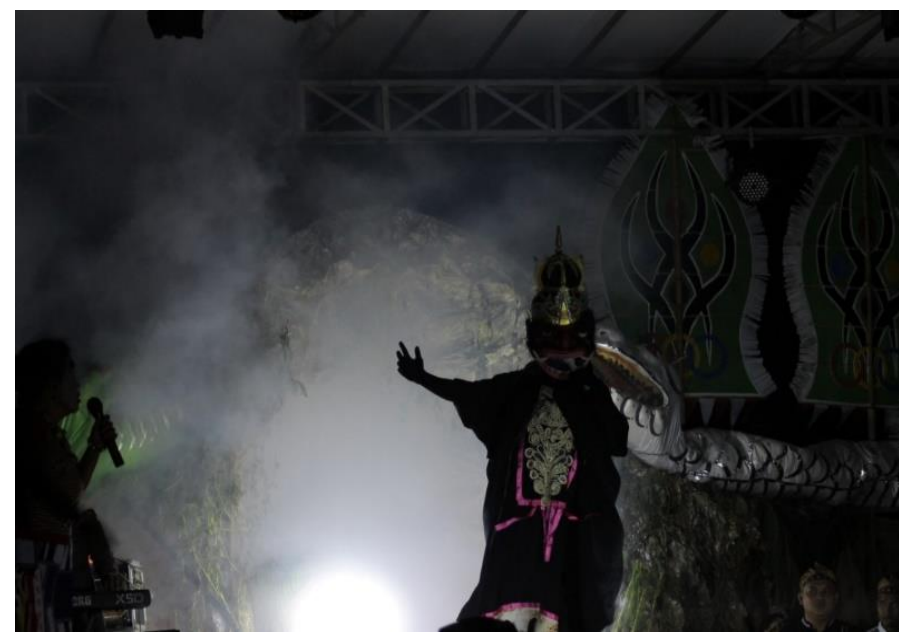

Fig 8:- The Scene of Play Cave Palace Festival of Mountain Kromong (Source; Researcher)
E. Glorification of the Natural, Social, Economic, and Cultural Arts Environment

The Gunung Kromong Festival is a space for the expression of the local community to embody cultural and artistic creativity in the theme of environmental, social and cultural arts. In the cultural parade (ider-ideran) the reflections of animals, railroad vehicles, mountains and cement factories are part of the cultural expression of the community to remind how the environment has begun to be damaged. Damage to the natural environment that has already occurred in his region needs to be reminded by the appearance of a cultural march. This nature theme becomes important to remind the people of Gempol sub-district that the environment has been surrounded by work activities of large companies, which cause environmental damage.

The environmental damage has an impact on social damage that causes the community does not have a sensibility towards others. Their lives have reflected the lives of industrial people who direct their people to work and work to eliminate the joints and national values. The orientation of industrial society is how they work to support their family or personal groups. Everything about work and social activities is measured by money and how much profit for the person. The social environment has changed from a modest social environment of rural communities to a hurried industrial society.

On the other hand, their cultural and artistic wealth is neglected so that their generation no longer knows the actual cultural environment of the people of the Gempol subdistrict. The new generation they are not familiar with the existence of cultural sites that have been lost and replaced with buildings and companies. Their art is lost and replaced with art that does not actually belong to the community.

Community phenomena are summarized in a Mount Kromong festival and the spirit of the festival. The phenomenon of how to restore the collective memory of the people of Gempol sub-district to regain social, cultural, and environmental life as it was in the current situation. The Festival of Kromong Mountain in glorifying cultural arts environment, social, and natural communities. The presence of art and cultural activities undertaken by the community re-created the collective work of the village community as before.

The Festival of Kromong Mountain opens the eyes of its people to participate in the festival. Not only ordinary people, officials also began to grow awareness of the importance of breeding arts and culture and social life, even though their nature has been damaged. Little by little they began to rebuild a form of glorification of their cultural arts, social life, and natural environment to empower the economy of the people. 
In economic empowerment, the festival of mountain kromong is aimed at developing tourism in the community. The reason this is important because there is working synergy between the performing arts and tourism areas that are able to develop and promote the arts and tourism aspects in the industrial era 4.0 that offers the transformation of economic life experience (experience economy). The creative industry of the performing arts in the world of tourism which is packaged in the festival can create a satisfying visitor experience, so they will come back to visit the next festival event (Manthiou et al., 2014).

Forms of performing arts festivals in the development of arts and culture-based tourism will have valuable experiences for tourists. Thus, Cetin \& Bilgihan (2016) asserts that the main motivation for developing the tourist activity in the destination is to create an experience with a way to enjoy a typical local performing arts. In Art, Tourism (Buczkowska and Magdalena Banaszkiewicz, 2015) says that art and tourism have been close since ancient times and tourists often deal with various arts according to their time and place. The opinion, further reaffirmed that the festival of performing arts area and $p$ Developing raises travel multi-players effect. This was reinforced by Melanie Smith's (2009 : 121) note that the development of performing arts is the creation of channels in the world of tourism that can obtain financial and moral support, help broaden the audience for art, and bring "style, culture, beauty, and a sense of continuity of life".

The Festival of Kromong Mountain is a cultural arts festival that is presented as an attraction in a tourist destination as an art tour. The authenticity of art tourism is considered important for the majority of cultural tourists. According to Anna Wieczorkiewicz (2012:53$54)$, the arrival of tourists in certain places, in turn, is an inspiration for local residents to "create traditions, to experiment and to introduce new elements of art and culture they possess".

An important conception of performing arts in tourism was recorded by Kim, et.al (2018) through conjoint analysis which sought to identify the most preferred performing arts tourism products in Indonesia. Through a different public test, researchers obtained a similar picture to Kim, et.al when they saw the enthusiasm of the community of tourist visitors increasing in Batu Lawang Cirebon tourism from 2018 to 2019.

Developing cultural arts festivals in tourist attractions is not solely to serve tourists but how the role of art can promote tourism. Thus Bhatta (2016) who mentioned the important role of art in promoting tourism. This method is highly recommended for the government as a strategy for partnerships between art, tourism and economic development because it is the key to growing strong tourism destinations.

\section{CONCLUSION}

From the overall community service research work, it can be concluded that through the work at the Festival of Kromong Mountain, a youth and community organization will be formed to hold the Festival of Kromong Mountain in a sustainable manner. This shows the solidity of social ties between young people in all villages in the Gempol sub-district, Cirebon Regency. This work also provides a pattern for the preservation of traditional art that is packaged in a procession (cultural march) and a performance (Gunung Kromong performing art ) which is packaged in the form of a typical festival, the Festival of Kromong Mountain .

The uniqueness of organizing the Festival of Kromong Mountain becomes a model of the festival of the people oriented to the mountain region with a consistent theme, namely glorification of cultural, social, and natural environment. Thus, the creation of a festival is part of the socio-cultural engineering work, in order to glorify the natural, social, economic, and cultural arts .

Finally, the Festival of Kromong Mountain became an important moment for the people of the Gempol sub-district of Cirebon, West Java, Indonesia, who are eagerly awaited every year to participate and enjoy the festival. The results of this festival illustrate how art and culture can revive people to glorify aspects of art, culture, social, economics, and the natural environment.

\section{ACKNOWLEDGMENT}

The Researcher is grateful to the Ministry of Research, Technology and Higher Education for providing funding in this study. Acknowledgments also the researchers conveyed to the Indonesian Cultural Arts Institute of Bandung for facilitating research work. The people of Gempol Subdistrict, Cirebon, West Java who provided space and cooperation for organizing this research work, the researchers thank you.

\section{REFERENCES}

[1]. Bhatta, Chiranjivi (2016) The Role of Arts in Promoting Tourism: A Case of Tourism Development in Thamel Area, Journal of Advanced Academic Research (JAAR). Jan Vol. 3. No. I. eISSN: 23621311 (Online)

[2]. Buczkowska, Karolina and Magdalena Banaszkiewicz (2015) "Art, tourism" in the Encyclopedia of Tourism, J. Jafari, H. Xiao (eds.). Switzerland: Springer International Publishing.

[3]. Cetin, G., \& Bilgihan, A (2016) Components of cultural tourists' experiences in destinations. Current Issues in Tourism, 19 (2), 137-154. https://doi.org/ 10.1080/ 13683500. 2014.994595

[4]. Fabiani, Jean-Louis, 2011. "Festivals, local and global: Critical interventions and the cultural public sphere" in Festivals and the Cultural Public Sphere. Edited by Giorgi, Liana. Monica Sassatelli 
and Gerard Delanty, Routledge 711 Third Avenue, New York.

[5]. Kim, Seongseop (Sam), et al. (2018) Determination of preferred performing arts tourism products using conjoint analysis, Journal of Vacation Marketing. Vol. 24 (1)

[6]. Manthiou, A., (Ally) Lee, S., (Rebecca) Tang, L., \& Chiang, L. (2014) The experience economy approach to marketing festivals: vivid memory and attendee loyalty. Journal of Services Marketing , 28 (1), 22-35. https://doi.org/10.1108/JSM-06-2012-0105

[7]. Ogburn, WF (1932). Social Change, Viking, New York

[8]. Sorokin, Pitirin. (1956). Social and Culture Dynamics. Boston: Porter Sargent.

[9]. Sulaiman, M. Munandar. (1998). The Dynamics of Transition Society: Finding Alternative Sociological Theories and Directions for Change. Yogyakarta: Student Library.

[10]. Salim, Agus. ( 2002). Social Change: Sketch of Theory and Reflexion Methodology Cash in Indonesia. Yogyakarta: Tiara Wacana .

[11]. Smith, Melanie (2009) Issues in Cultural Tourism Studies. London: Routledge.

[12]. Wieczorkiewicz, Anna. (2012) Apetyt Turysty. O Doswiadczaniu Swiata w Podrozy (The Appetite of a Tourist. The Experience of the World in Travel). Krakow: University., 44-61. sagepub.co.uk/ journals Permissions. nav DOI: 10.1177 / 1356766716679484. 